\title{
A Subnational Assessment of Hotel Social Media Metrics - the Case of Serbia
}

\author{
Časlav Kalinić ${ }^{A^{*}}$, Miroslav Vujičićc ${ }^{A}$ \\ Received: December 20, 2018 | Revised: March 21, 2019 | Accepted: March 22, 2019 \\ DOI: $10.5937 / g p 23-19968$
}

\begin{abstract}
Facebook is the most widely used SNS (Social Networking Sites) platform globally, and it represents an important marketing and communication channel for hotels. The dynamic and constantly changing nature requires continuous adaptation to changes and benchmarking in order to identify best practices. This paper investigates selected characteristics of Facebook pages (social media metrics) of all hotels in Serbia in national regional context. In the case of four explored regions of Serbia, the results indicate regional inconsistencies, with most notable differences within the number of page fans, temporal aspects of posts as well as user engagement. On the other hand, similarities are evident in some post characteristics such as type of post and post length, while a specific pattern can be observed concerning page fans country of origin. This paper contributes to the regional understanding of social media metrics that can help hotels when assessing their promotional activities.
\end{abstract}

Keywords: social media metrics; hotels; subnational assessment; Facebook; Serbia

\section{Introduction}

Facebook is currently the most widely used and influential social network on the Internet and one of the most popular websites worldwide (Jovanović et al., 2018). On December $31^{\text {st }} 2017$, Facebook had reached 2.13 billion monthly active users, nearly half the world's estimated online population (Internetworldstats, 2018). This social network is an essential component of marketing activities for many companies (Dragović et al., 2018)a large number of people use the Internet for a variety of purposes. There is a growing presence of social networks in different spheres of life. Consequently, the connection of national parks and social media has begun. In this way, the management of national parks is facilitated in general, because data from social media can be of great help. Communication with visitors of national parks, through social media, has great potential in protecting such areas, but also in providing a wealth of experience. There- fore, it is essential to constantly update and direct visitors to the official Facebook sites of national parks. In this paper, the presence and activity of national parks sites on Facebook, in Former Yugoslavia (Bosnia and Herzegovina, Croatia, FYR Macedonia, Montenegro, Serbia and Slovenia. Many hotels have recognized this (Hsu, 2012; Kwok \& Yu, 2013), thus moving focus in hospitality industry and academic research from Facebook presence and adaptation to the matters how to use it and how to create strategies for managing Facebook Pages (De Vries et al., 2012; Mariani et al., 2016; Sabate et al., 2014)engagement and word of mouth. In this context, the analysis of the factors that are conditioning consumer interaction with branded content becomes a matter of interest. This paper aims to shed light on those factors that are expected to impact on Facebook branded post popularity. A conceptual model is developed to reflect the influence of the con-

\footnotetext{
A University of Novi Sad, Faculty of Sciences, Department of Geography, Tourism and Hotel Management, Trg Dositeja Obradovića 3, 21000 Novi Sad, Serbia

* Corresponding author: Časlav Kalinić; e-mail: caslavkalinic@gmail.com
} 
tent's richness and time frame on the number of comments and likes. An empirical analysis using multiple linear regressions is conducted based on 164 Facebook posts gathered from the fan pages of 5 Spanish travel agencies. Results suggest that the richness of the content (inclusions of images and videos.

The dynamic nature of SNS, and constant changes in functionalities, have consequences in two ways. Firstly, this makes research on this subject outdated in a very short period of time (Kaplan \& Haenlein, 2010; Lu \& Stepchenkova, 2015; Zouganeli et al., 2012). On the other hand, this places an obligation on hotel managers to follow constant changes in various social media platforms. SNS can be detrimental for hotel success since they provide a platform for building communication with customers (Roque \& Raposo, 2016; Sparks \& Browning, 2011) as well as for monitoring the competitor's use of these platforms (He et al., 2013). These are continuous processes within hotel marketing efforts (Chaffey \& Ellis-Chadwick, 2016). This kind of benchmarking can help identify the best practices and marketing standards with the goal of improving online promotional strategies (Chan \& Guillet, 2011; Fan et al., 2015). The changing nature of
SNS platforms also means that new features and approaches that are accepted by both customers and competitors could soon become regular elements of social media strategies, thus being expected by new customers as well.

Internet penetration in Serbia has increased significantly in the last decade, reaching $72.2 \%$ in 2017 , which is still below the European (85.2\%), but also above the global average (54.4\%) (Internetworldstats, 2018). The reason for this can be found in the increase in the popularity of social networks. In Serbia, there were 3.6 million users of Facebook in 2017, meaning that 51\% of the population used this social network, which is above the global (26.3\%) and European (41.7\%) average (Kemp, 2018). According to the Statistical Office of the Republic of Serbia (Statistical Office of the Republic of Serbia, 2017), a large number of Internet users in Serbia spent time online using social networks (67.8\%), while $7.9 \%$ of them used the Internet to book travel accommodation. According to the same survey, $37.5 \%$ of companies used social networks in their business. Since one of the important characteristics of a hotel product or service is inability to test it before consumption, the importance of the Internet and so-

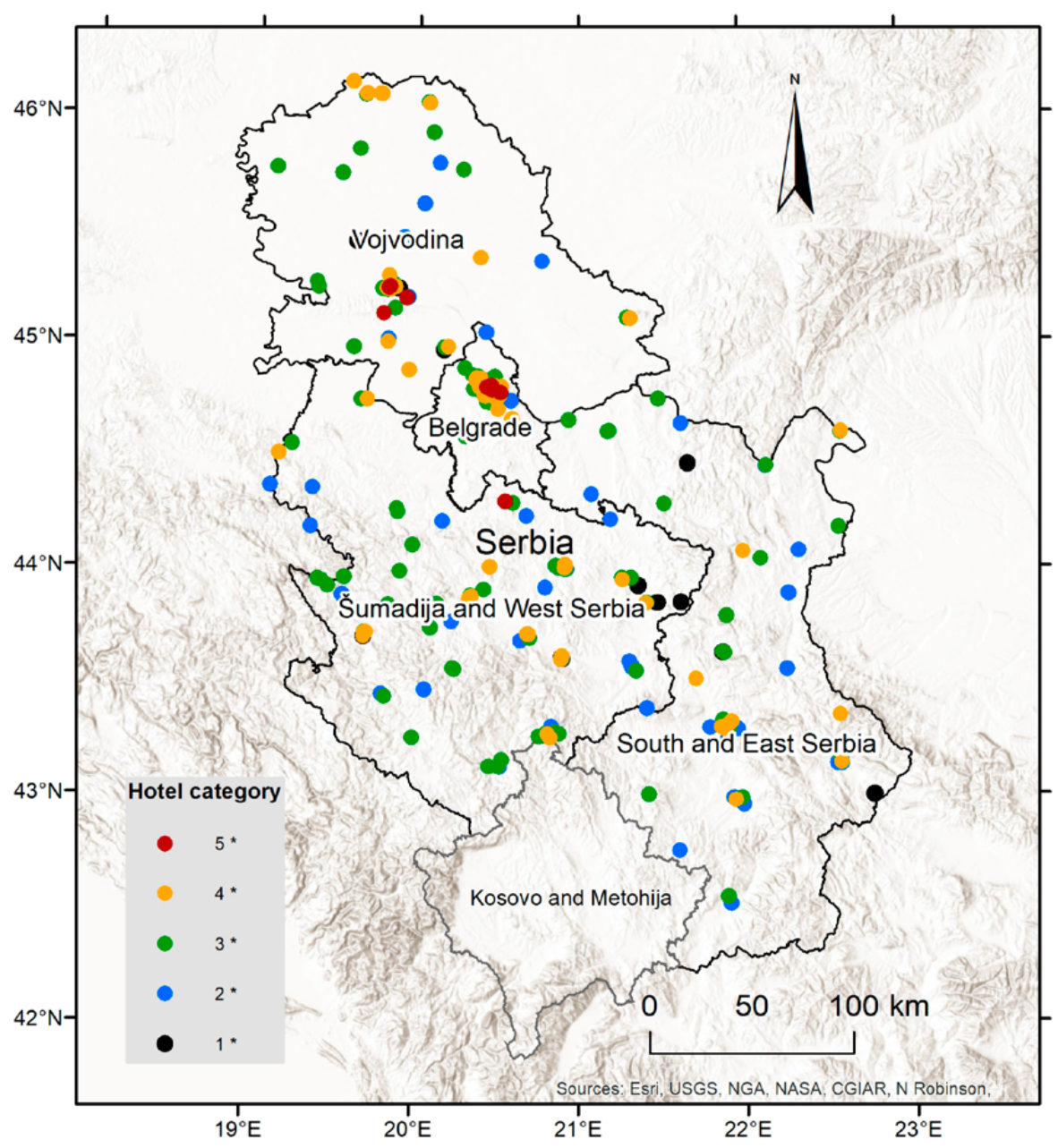

Figure 1. Spatial distribution of hotels by category across Serbia's regions 
cial networks in promotion is greater in this business sector.

Every region has its own characteristics in terms of amenities offered to visitors and hotel guests (Lee et al., 2018). The same can be said for perceived image of the region as well as their brand position on the market. In that regard, rural areas have been considered major tourism destinations due to abundance of natural amenities (Truchet et al., 2011). On the other hand, urban development emphasized significance of urban amenities. Researches in various fields focused increasingly on the role of tourism in urban areas, since it is considered to contribute to city's image and because tourist can support local economy (Beauregard, 200o). In addition, some urban destinations, such as Belgrade and Novi Sad in case of Serbia, positioned themselves not only as destinations serving tourism and hotel businesses, but also as MICE markets. Therefore, amenities need to be understood in the broader context of the tourism supply system, comprised of attractions, transportation, services, information and promotion (Gunn, 2002). In that regard, some authors (Sharpley \& Telfer, 2014) emphasized the lack of theoretical advances in the area of regional tourism development.
Under the influence of globalization and interregional competition, it is vital for regions to be entrepreneurial in their efforts to attract capital with the aim of strengthening their positions (Peck et al., 2009). In that regard, regional authorities are focusing on urban development attempts that favor amenities development as a driver of consumption attraction. Many of these spaces are providing amenities to tourists as well as residents. In that regard, hotels are considered the main carriers of tourism material base, making their marketing and promotional efforts important for the success of aforementioned regional development.

Although, understanding the hotel industry from a spatial perspective is important (Lee et al., 2018; Luo \& Yang, 2013), tourism and hospitality researchers have paid little attention to hotel research on a national scale, as well as regional breakdown and comparison. Ubiquity of social media makes it important marketing and promotion channel, with the potential for reaching markets worldwide in a much convenient and cheaper way compared to traditional marketing methods. Thus, this paper provides a rear insight into subnational (regional) aspects of hotels social media activities and metrics, carried out on Facebook during a period of one year.

\section{SNSs and Social Media Marketing of Hotels}

As far as the hotel and tourism sector are concerned their non-material nature of products and services that cannot be tested before consumption an adequate information about them has much more importance for consumers than in the case of material goods (Stankov et al., 2010).

Hotel business in Serbia has been in the expansion stage in recent years (Stankov et al., 2017). One of the reasons that has significantly contributed, in addition to increasing the number of tourists, the use of online reservation systems and promotion through the Internet and social networks (Inversini \& Masiero, 2014).

Although hotel industry is not primarily technology-oriented, developments in information technology largely influenced the way they function, primarily driven by user demands (Buhalis \& O'Connor, 2005). Some authors believe that the application of information technology in the hospitality industry represents a new period in the development of this segment of the economy and can significantly contribute to the increase in user satisfaction (Kimes, 2008; Law \& Jogaratnam, 2005). An increasing number of users search for information and book hotels online (Pan et al., 2013). In the application of information technologies, one of the most important trends is the use of social networks by both hotels and users. Many individuals now use so- cial networks at various stages of travel planning (Lo et al., 2011; Schmallegger \& Carson, 2008; Tussyadiah et al., 2011; Yoo \& Gretzel, 2012), and are significantly influenced by electronic word of mouth (Litvin et al., 2008). In addition, the use of social networks also influences the development of users' preferences in terms of hotel choice (McCarthy et al., 2010), while the probability of booking is significantly determined by online reviews (Sparks \& Browning, 2011). Social networks are an important factor not only for the search of hotel information, but also for the hotel itself, as an important marketing tool (Chan \& Guillet, 2011; Huang et al., 2011; Inversini et al., 2009; Kasavana et al., 2010; Xiang \& Gretzel, 2010). Promotion is one of the most important functions carried out using social networks. However, in order for it to be adequate, hotels must actively monitor social networks in order to gain a better insight into the users and the way in which they are perceived, while noting the possible ways to improve their products (Litvin et al., 2008; Pantelidis, 2010). In addition, social networks facilitate communication with users, which also leads to their better interaction, understanding their preferences and needs (L. Huang et al., 2011). Apart from the fact that this is the way to increase the brand loyalty and keep existing users, it can also affect the acquisition of new users. 
The use of social media in communication with users relates primarily to building interaction with them and creating unique connections, thus positively influencing eWoM (Electronic Word of Mouth) (Huang et al., 2010; Li \& Wang, 2011; Pantelidis, 2010; Schmallegger \& Carson, 2008). In addition, by communication on SNSs, organizations can collect relevant information on aspects of their products and services, which users consider important, and their satisfaction with these aspects (Marine-Roig \& Anton Clavé, 2015; Xiang et al., 2015). In addition, hotels can encourage participation of users in creating future products and services, to help them meet their needs. While participation of users in communicating with hotels on social media has many benefits, this also means that users participate in the creation of the image of the hotel. Therefore it is extremely important that opinions and attitudes of users are positive in order to contribute to the creation of a positive image (Ladhari \& Michaud, 2015). The role of social media in management itself is essential from the aspect of collecting information and making decisions based on them, because they allow cutting costs, through better retention of existing customers.

Structure and content analysis of the hotels social network activity can provide extremely valuable information on the practice of communication with users. In this way, it can be determined which type of content positively affects the engagement of the user, whether it is a photo, video or text, or a combination of the listed ones. For the promotional activities of the hotel on social networks, it is also important to determine the timeline of these activities. This implies the frequency of hotel announcements on the page, which days show more user engagement, as well as time of the day with increased user activity (Kwok \& Yu, 2013; Mariani et al., 2016; Zivkovic et al., 2015).

In his research, Pantelidis (Pantelidis, 2010) emphasizes the importance of monitoring and manage- ment of social media communications, and states that social networks provide the opportunity for hotels not only to better understand how consumers perceive them, but also to point out certain aspects of products and services that can be improved.

Somewhat older data on Hong Kong hotel activities on social networks (Chan \& Guillet, 2011) indicates that a number of hotels have failed to facilitate interaction and communication on their social networking sites profiles. Also, although many hotels are present on social networks, their level of activity and engagement in conversation with consumers is low, so this communication channel in the promotion can be ineffective (O'Connor, 2011).

Social networks represent a significant promotional channel and are often used in hotel practice, since they allow the publication of information to users, as well as links with other people of similar interest (Dippelreiter et al., 2008; Y. Huang et al., 2010). Kasavana, Nusair and Teodosic (Kasavana et al., 2010) recognize business potential of Facebook, primarily as a digital marketing tool that allow hotels to reach the international auditorium. Research on the use of Facebook for promotional purposes, and on the example of 67 hotels in Hong Kong (Chan \& Guillet, 2011), this social network is most popular for communicating with consumers.

The same authors believe that what hotels can certainly do within their promotional activities is to stimulate demand, provide links to their websites and direct booking platforms, in order to increase the likelihood of purchasing by consumers. Precisely because most bookings happen online, the hotel sector is particularly sensitive to online communication with consumers, and negative opinions or efforts to direct users to book accommodation can have a significant impact on the success of hotel promotions on social networks (Ye et al., 2011).

\section{Methodology}

For the purpose of the data collection for this research, we focused on a manual and automated approach. The official database ${ }^{1}$ of hotels as of October 2017, was acquired from Ministry of trade, tourism and telecommunications website. The database contained name, category, and address for each hotel. Based on addresses provided, hotels were classified according to the region where they are located. After that, the search included each hotels website and official Facebook page.

\footnotetext{
1 The database didn't contain information about hotels in the 5 th region, Kosovo and Metohija, therefore that region is not part of the analysis
}

The data for Page posts was gathered automatically using page data module of Netvizz v1.25 tool. This Facebook tool extracts data from different sections of the Facebook Groups and Pages (Rieder, 2013). Extracted data include information such as: Facebook's post classification, text of the post, picture URL (if a picture is attached to the post), publishing date and time, number of likes, comments, shares, etc). Information regarding number and country of origin of Page fans was also collected using this tool and method. Only the content posted by hotels was acquired.

The authors gathered information on 22839 published posts over the period of one year, from November $1^{\text {st }} 2016$ 
to October $31^{\text {st }}$ 2017. Data collection took place during December 2017. This was necessary, in order to see how fans interacted with the post. This time span between actual posting time and time of data gathering is believed to be long enough for the purpose of this study. According to Sabate et al. (2014), a content post on the net is not likely to receive further significant interaction after a period of one month since publishing, especially in the case of Facebook that is extremely dynamic SNS.

Analysis of the structure of Page fans found an unusually large number of fans from Bangladesh (29118), Nepal (41930), and Pakistan (4144) among Page followers of hotels in Belgrade region. Since instances of buying followers happen on SNS (Cellan-Jones, 2012; Facebook for Business, 2018), it is possible to assume that this is the case with the mentioned Page fans. Additionally, these countries are not significant tourist emitting market, at least not for Serbian market, and the number of Page fans from these countries significantly exceeds the number of foreign tourists from "other non-European countries" during the research period, according to the records of the Statistical Office of the Republic of Serbia. Therefore, Page fans from these countries were excluded from the analysis in order to improve accuracy of the results.

\section{Variables}

The information gathered for each Facebook Page is presented in Table 1. It is based on the literature review above and capabilities of Facebook API at the time of data gathering. Information about Pages is divided into two groups. The first one having general information about page popularity and the second consisting of page activity, including user engagement metrics.

\section{Results}

\section{Page popularity}

Page popularity metrics showed contradiction among regions in different categories. Hotels in the region of Šumadija and West Serbia have the most total Page fans, over six hundred thousand (Table 3), but at the same time this is the region with most hotel pages on Facebook. The fact that some of the most popular destinations in Serbia, such as Zlatibor, Kopaonik, and Vrnjačкa banja (Statistical office of the Republic of Serbia, 2017), are located in this region can provide the background for such results.

On the other hand, the highest average number of Page fans is recorded in Vojvodina region, 9300, followed by region of East and South Serbia with 7460 average Page fans, two regions with least number of hotels carrying out their marketing efforts on Facebook.
Table 1. Page popularity

\begin{tabular}{|l|}
\hline Page popularity \\
\hline Number of Page likes/fans \\
\hline Page fans country of origin \\
\hline
\end{tabular}

Facebook post metrics are divided into two main groups. First group includes basic metrics of users' engagement: „Reactions” (indicating interest in an existing post), "Comments" about the post content, and "Shares". The last one consisted of the content on personal Profile or other Pages or Groups and posting content on the Page's wall (depending on the communication policy set by the Page owner) (De Vries et al., 2012; Pletikosa Cvijikj \& Michahelles, 2013; Sabate et al., 2014; Stankov et al., 2018). Second group consists of content metadata characteristics, including length of post, time of posting, day in the week when content is posted and type of post (link, photo, video, status or event).

Table 2. Page activity

\begin{tabular}{|l|l|}
\hline \multicolumn{2}{|l|}{$\begin{array}{l}\text { The information (variables) gathered for user's } \\
\text { engagement and post metadata }\end{array}$} \\
\hline User engagement & Description \\
\hline Reactions & $\begin{array}{l}\text { Number of total reactions a post } \\
\text { received }\end{array}$ \\
\hline Comments & $\begin{array}{l}\text { Total number of comments a post } \\
\text { received }\end{array}$ \\
\hline Shares & Total number of shares a post received \\
\hline Post metadata & Description \\
\hline Length of post & $\begin{array}{l}\text { The number of characters in the post, } \\
\text { including the characters of links }\end{array}$ \\
\hline Time of posting & Coordinated Universal Time (UTC) \\
\hline Day of posting & self-explanatory \\
\hline Type of post & status, photo, video, link, or event \\
\hline
\end{tabular}

However, in case of both regions, one hotel page has around two hundred thousand fans, much more than the rest, even on national level. Generally, in all four regions, the number of Page fans varies from less than thousand to some larger fan communities counting more than 50 thousand fan base. What is especially notable is high percentage of Pages with less than one thousand fans. That percentage is lowest in Vojvodina region, where $17 \%$ of Pages belong to this category, followed by hotels located in the region of Šumadija and West Serbia, 23\%. Much higher percentage is among hotels in regions of East and South Serbia and Belgrade, $43 \%$ and $39 \%$ respectively.

In terms of Page fans country of origin, region of Šumadija and West Serbia showed highest diversity, recording fans from 137 countries. That number is 
Table 3. General information of hotel Facebook pages (by regions)

\begin{tabular}{|l|r|r|r|r|r|r|r|}
\hline & $\begin{array}{l}\text { Total Hotels } \\
\text { in the } \\
\text { Region }\end{array}$ & $\begin{array}{c}\text { Hotels with } \\
\text { Facebook } \\
\text { Pages }\end{array}$ & $\begin{array}{c}\text { Hotels with } \\
\text { Facebook } \\
\text { Pages (in \%) }\end{array}$ & $\begin{array}{c}\text { Total Page } \\
\text { Fans }\end{array}$ & $\begin{array}{c}\text { Average } \\
\text { Fans per } \\
\text { Page }\end{array}$ & $\begin{array}{c}\text { \% of } \\
\text { Domestic } \\
\text { Page fans }\end{array}$ & $\begin{array}{c}\text { Fans from } \\
\text { Countries }\end{array}$ \\
\hline Vojvodina & 64 & 49 & $76.6 \%$ & 437119 & 9300.4 & $69.42 \%$ & 120 \\
\hline Belgrade & 93 & 77 & $82.8 \%$ & 391362 & 6059.14 & $64.29 \%$ & 119 \\
\hline $\begin{array}{l}\text { Šmadija and } \\
\text { West Serbia }\end{array}$ & 116 & 88 & $75.9 \%$ & 633759 & 7201.8 & $72.87 \%$ & 137 \\
\hline $\begin{array}{l}\text { East and South } \\
\text { Srbija }\end{array}$ & 63 & 44 & $69.8 \%$ & 328280 & 7460.9 & $70.09 \%$ & 114 \\
\hline
\end{tabular}

somewhat lower for Vojvodina region, 120, Belgrade region, 119, and East and South Serbia, 114. Although hotels from Šumadija and West Serbia region have Page fans from most number of countries, they had the least share in total Page fans. Domestic Page fans were majority with $72.9 \%$, which is more than in East and South Serbia, 70.1\%, and Vojvodina, 69.4\%. Belgrade region had the least share of fans from Serbia, although they still represented majority with $64.3 \%$ of total Page fans.

There are also differences among regions when structure of foreign fans is concerned. Distribution of foreign Page fans in Vojvodina region (Figure 2) showed that fans from all former Yugoslav republics are present among the top 10. One quarter of all foreign page fans are from Bosnia and Herzegovina, followed by fans from Croatia with $14.2 \%$, the only two former Yugoslav countries that border Vojvodina region. Significant percentage of fans can also be found in Montenegro and Macedonia (FYROM), from where $12.5 \%$ and $10.4 \%$ of fan base come from. Page fans from Germany have $7.7 \%$ share among foreign fans, from Austria $4.7 \%$, neighboring Romania $2.4 \%$, while $2 \%$ of foreign fans from United States represent the only non-European fans among the top 10 countries of origin.
Belgrade region is most popular among foreign visitors, with $57 \%$ of all foreign visits to Serbia in 2017 , taking place here. Therefore, it is especially important to understand the structure of foreign Page fans of hotels located in this region. In this case, as well, fans from former Yugoslav republics dominate the top 10 countries of origin (Figure 3). However, most of them are from Macedonia (FYROM), 22.2\%, followed by fans from Montenegro, $12 \%$, and Bosnia and Herzegovina, $11.8 \%$. It is also notable, that in case of this region, fans from Turkey, 5.2\%, Bulgaria, 3.8\%, and Greece, $3.2 \%$, are present on this list.

Although the distribution of Page fans by country of origin showed that the hotels in the region of Šumadija and West Serbia has the greatest variety in this category, majority of foreign fans are only from a few countries (Figure 4). Almost one third of the foreign Page fans are from Bosnia and Herzegovina, country that this region borders to the west. Fans from Montenegro, also neighboring country, make up $18.2 \%$ of foreign fans. Only one more group of page fans are prominent, $12.4 \%$ of them from Macedonia (FYROM). Other countries have less than 10\% share among the page fans, and the list concludes with US page fans that make $1.9 \%$ of total foreign fans.

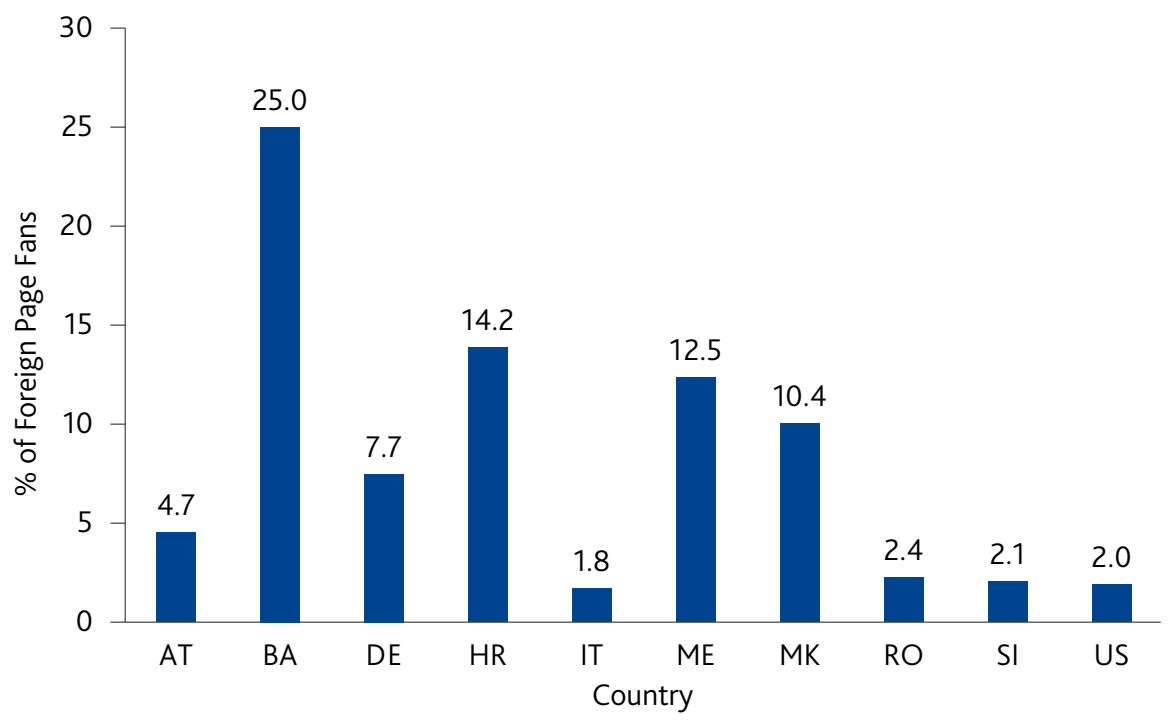

Figure 2. Structure of Vojvodina hotels foreign page fans by country of origin 


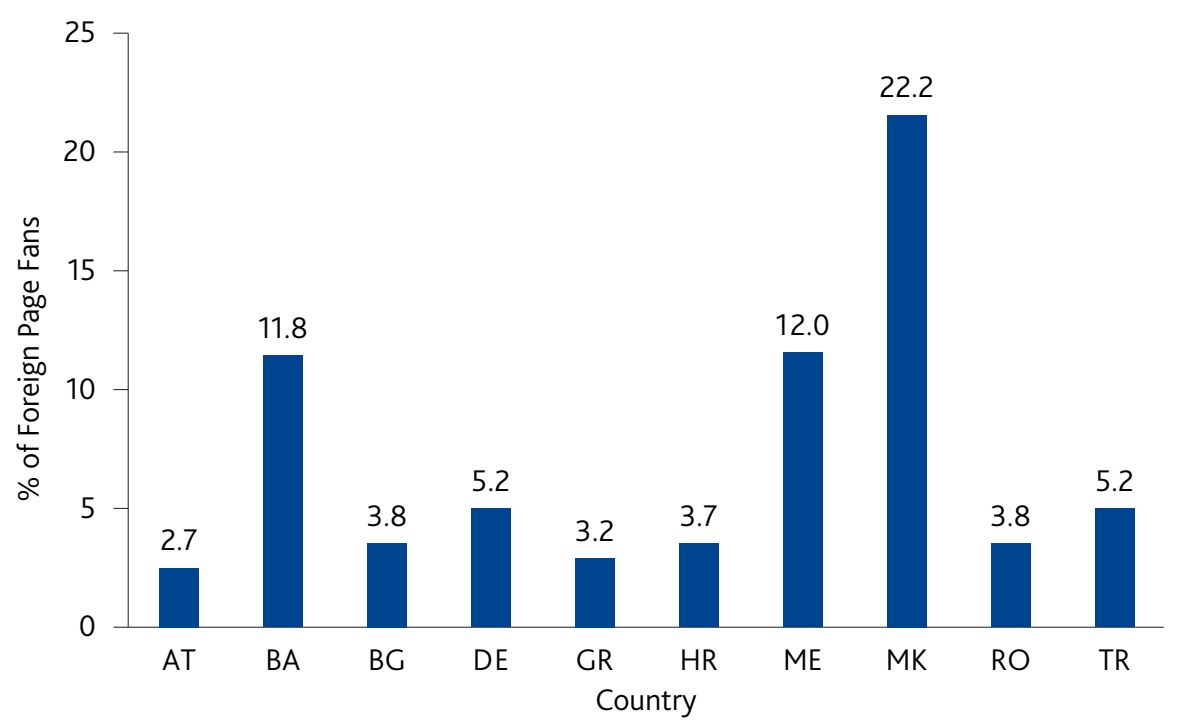

Figure 3. Structure of Belgrade hotels foreign page fans by country of origin

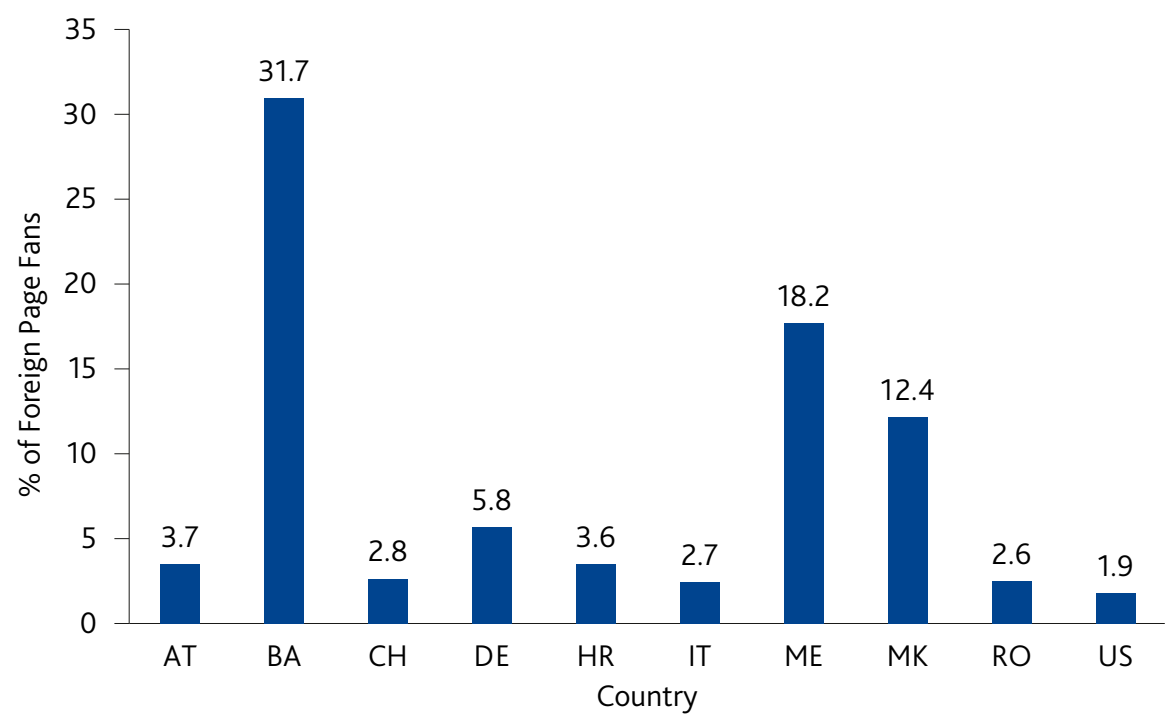

Figure 4. Structure of Šumadija and West Serbia hotels foreign page fans by country of origin

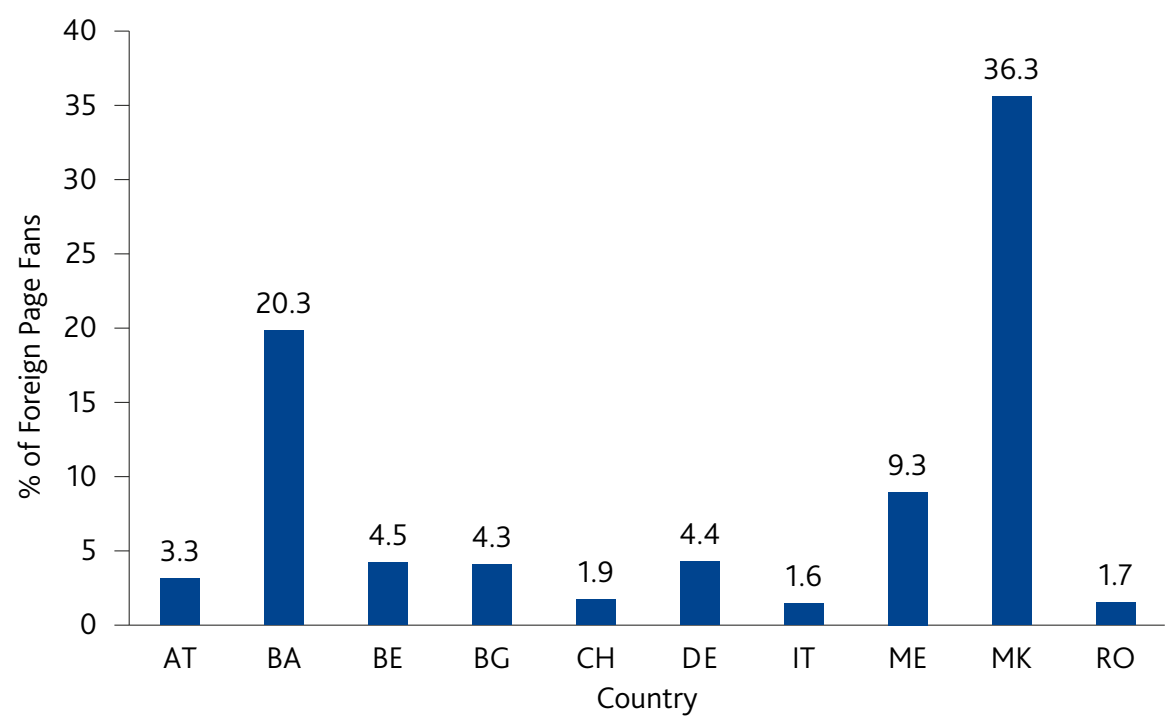

Figure 5. Structure of East and South Serbia hotels foreign page fans by country of origin 
In case of region of East and South Serbia, a rather similar pattern can be observed when it comes to fans country of origin (Figure 5). Here too, majority of hotels Page fans are from former Yugoslav republics. Similarly, most of them are from neighboring country, in this case from Macedonia (FYROM), the country that this region borders to the south, and from where $36.2 \%$ of Page fans are. Another larger group is comprised of fans from Bosnia and Herzegovina, 20.3\%, while also fans from neighboring countries are present on this list, Bulgaria, 4.3\% and Romania, $1.7 \%$.

\section{User engagement and post metadata characteristics}

As shown in Table 4, photos are dominant type of posts as in each of four regions they represent more than $70 \%$ of all posts. Links are second most popular type of posts in three regions, comprising $14.07 \%$ of all posts in Vojvodina region and $10.51 \%$ in Belgrade region. Videos are only second popular type of post in case of East and South Serbia region, but even in that case only $7.45 \%$ of all posts account for this type. Statuses and events are least popular type of posts, since they account for only a few percent of posts in each region.

Table 4. Type of posts

\begin{tabular}{|l|r|r|r|r|}
\hline & Vojvodina & Belgrade & $\begin{array}{c}\text { Šumadija } \\
\text { and West } \\
\text { Serbia }\end{array}$ & $\begin{array}{c}\text { East and } \\
\text { South } \\
\text { Serbia }\end{array}$ \\
\hline Status & $3.02 \%$ & $1.09 \%$ & $2.88 \%$ & $2.43 \%$ \\
\hline Photo & $73.72 \%$ & $82.27 \%$ & $81.72 \%$ & $83.73 \%$ \\
\hline Video & $7.54 \%$ & $4.85 \%$ & $7.14 \%$ & $7.45 \%$ \\
\hline Link & $14.07 \%$ & $10.51 \%$ & $7.42 \%$ & $5.38 \%$ \\
\hline Event & $1.61 \%$ & $1.26 \%$ & $0.84 \%$ & $1.02 \%$ \\
\hline
\end{tabular}

The analysis of the post length in characters, which included posts that contained text, including texts of links, showed differences among regions Table 5. The shortest average post length was recorded in posts from hotels in Vojvodina region, 134.17 characters. Lengthier on average, were posts from hotels in East and South Serbia and Šumadija and West Serbia regions, while the highest average post length was recorded in Belgrade region. Generally, each case fall into Facebook recommendation that post length should be between 100 and 250 characters in order to be more appealing and generate more user engagement (Gessler, 2016). In terms of frequency of posting, the analysis determined that in case of all four regions hotels post once in four days on average.

Table 5. Average post length in characters (including characters in links)

\begin{tabular}{|l|r|r|r|r|}
\hline & Vojvodina & Belgrade & $\begin{array}{l}\text { Šumadija } \\
\text { and West } \\
\text { Serbia }\end{array}$ & $\begin{array}{c}\text { East and } \\
\text { South } \\
\text { Serbia }\end{array}$ \\
\hline $\begin{array}{l}\text { Avg. } \\
\text { Post } \\
\text { Length }\end{array}$ & 134.17 & 218.47 & 165.88 & 187.44 \\
\hline SD & 184.47 & 284.16 & 172.68 & 237.12 \\
\hline
\end{tabular}

Distribution of posts during a year presented in Figure 6, showed different results. Hotels in Vojvodina region posted the most during December and January, while they were least active from May to July, period with lowest number of posts. On the contrary, in case of hotels in East and South Serbia region, who posted the most during this period, except that they recorded the highest value during December. Hotels

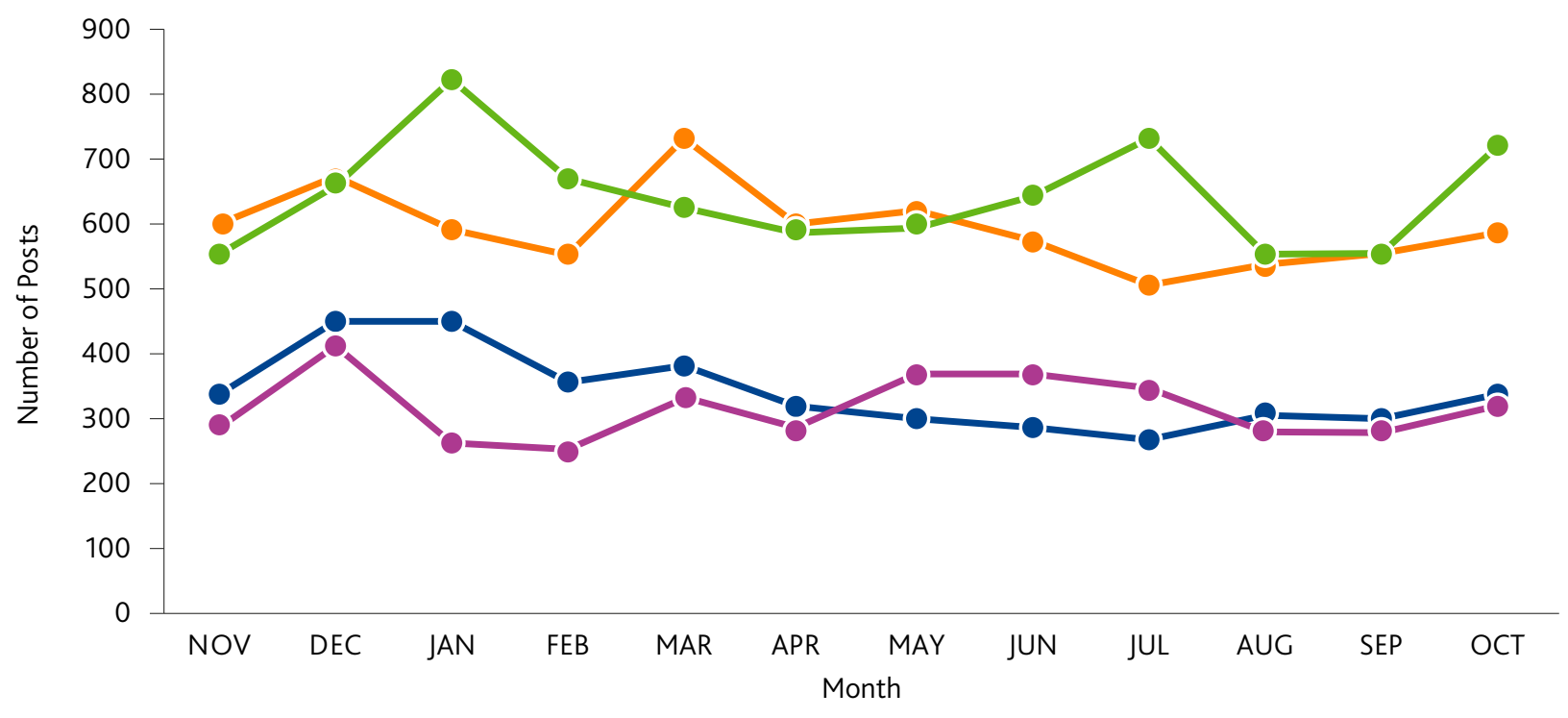

- Vojvodina $-0-$ Belgrade $-0-$ Šumadija and West Serbia $\quad-$ East and South Serbia

Figure 6. Post distribution during a year 


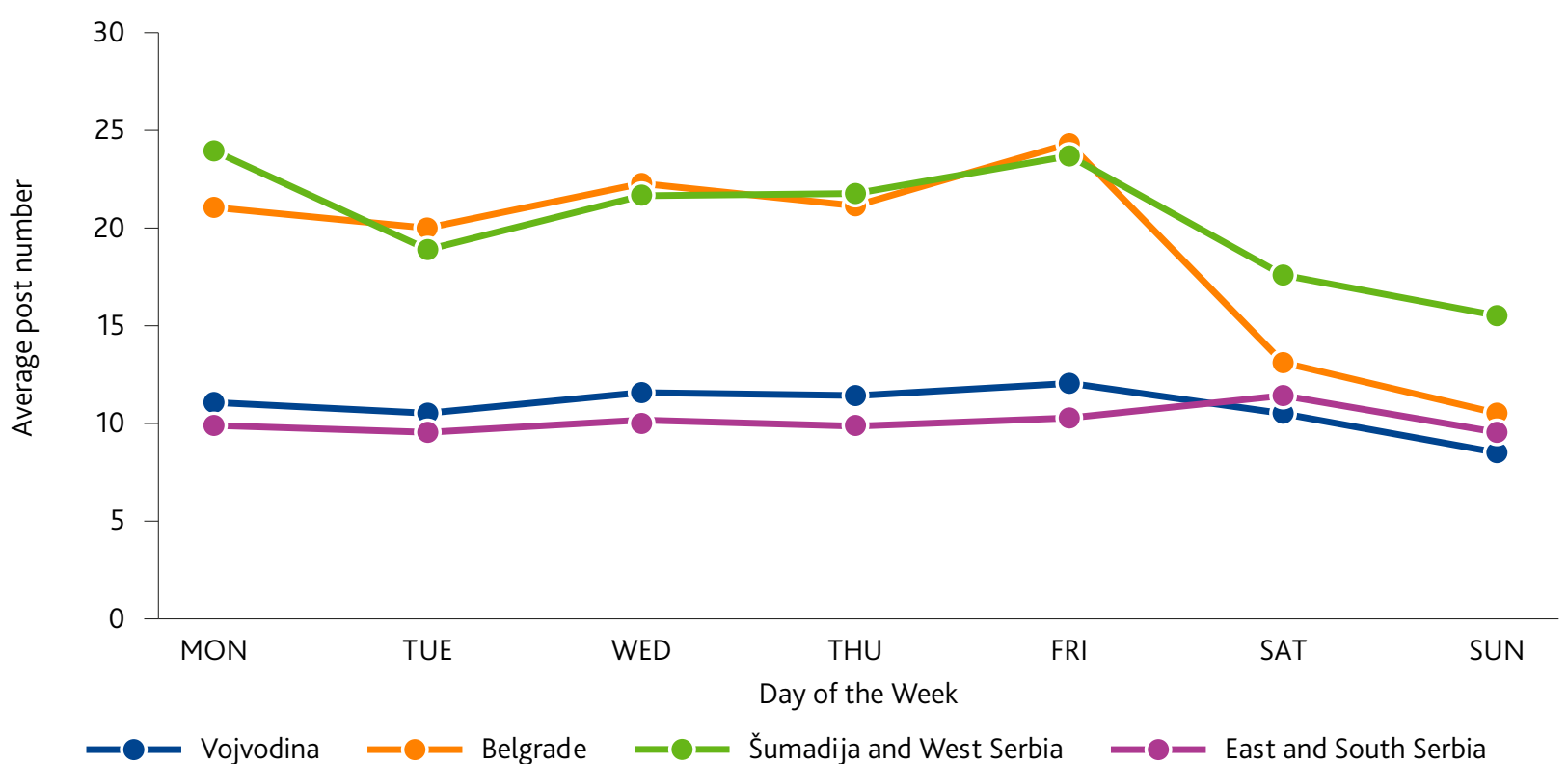

Figure 7. Average weekly post distribution

in Belgrade region, posted the most during March, followed by December, while the lowest number of posts is recorded during July. This is in contrast to hotels in Šumadija and West Serbia region, in which case the number of posts in July fall behind only after the value in January, and before October postings.

Weekly distribution of Page posts (Figure 7) showed that in most cases, hotels posted less during weekends. In case of Belgrade and Šumadija and West Serbia regions, the drop in number of posts during weekends is more prominent, while in case of hotels in Vojvodina region, it is only a slight decline compared to work days. The only exception is in the case of hotels in East and South Serbia region where the highest average number of posts is recorded on Saturday, but only by a small margin, compared to average number of posts during others day of the week.

Daily Page post distribution is presented in Figure 8. While hotels from all four regions post the least during night, beginning of typical working hours (8.00) proved to be the mark after which different posting patterns can be observed. Posts of hotels in Vojvodina region were equally distributed throughout the day until evening hours, with just the slight increase between 11.00 and 14.00. The increase of number of posts during the same time of the day is recorded in Belgrade region as well, although to a much higher degree, with the peak around 11.0o. In case of hotels

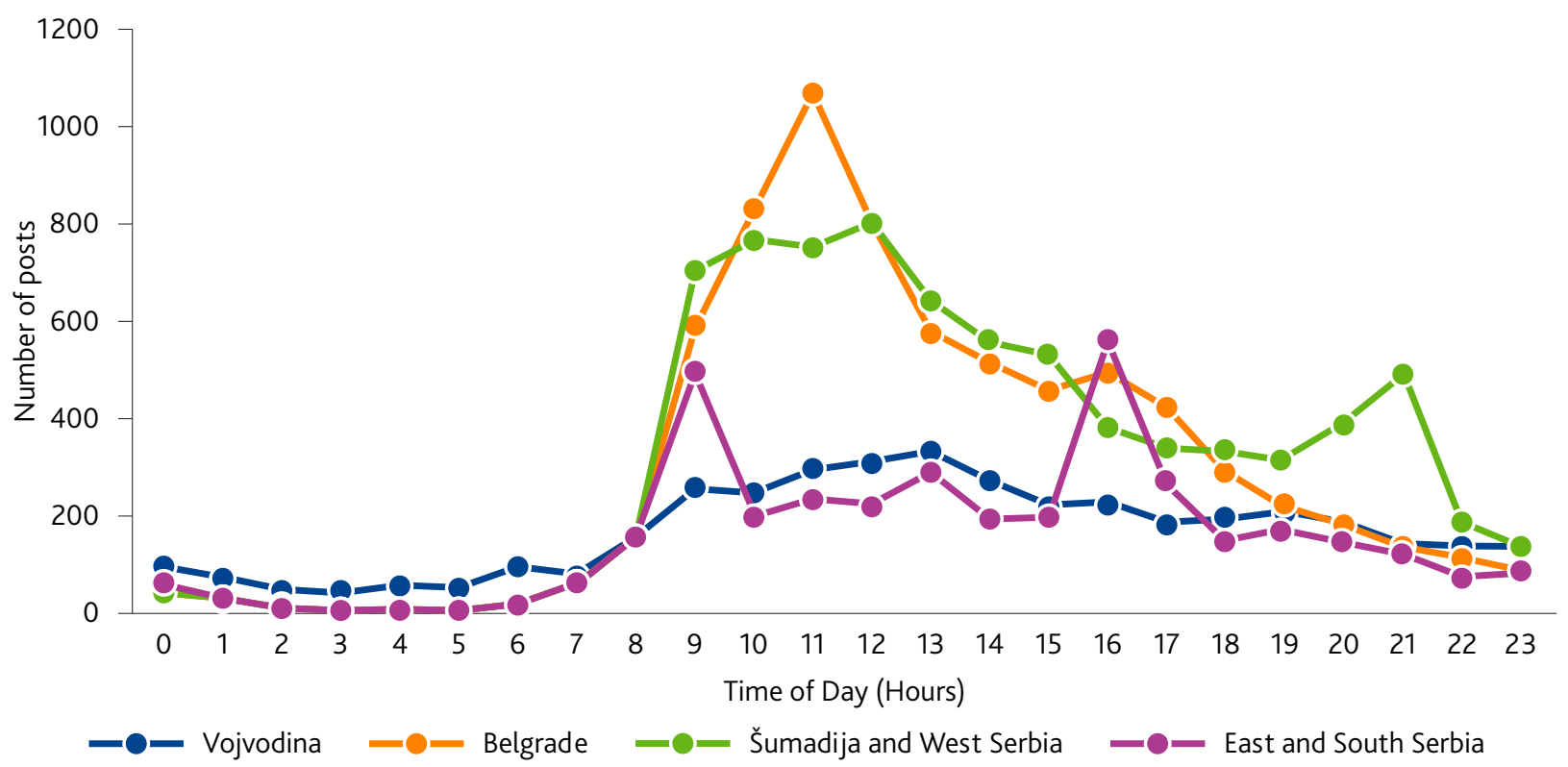

Figure 8. Daily post distribution 
in Šumadija and West Serbia region, the increase in number of posts start earlier, at 9.00, and lasts until 13.00, in order to peak again at 21.00. As far as East and South Serbia region is concerned, with the least number of posts in this group, two peaks are recorded at different times. The first one is around 9.00, and the second around 16.00. This not only differs from daily posting patterns of hotels from other three regions, but also coincide roughly with the beginning and the end of typical working hours in Serbia.

The results shown in Table 6 indicate there are differences for three observed variables in all four regions. Reactions were predominant way of user engagement in all cases, although means differ across the regions. The least engagement was recorded in Vojvodina region, where posts averaged 29.96 reactions, while this number is higher for Belgrade region, 44.46. Hotels in Šumadija and West Serbia region averaged 71.72 reactions per post, more than double compared to Vojvodina region, while the highest score is recorded in East and South Serbia region, 101.83 reactions per post, more than three times more than in the case of first region. The order of the regions is the same in case of comments, where hotels in Vojvodina and Belgrade region received less than one comment per post, 0.51 and 0.56 respectively. This metric was higher in case of Šumadija and West Serbia and East and South Serbia regions, 1.13 and 1.61 respectively. Shares proved to be second popular way of user engagement in all regions. As in case of other two variables, posts in Vojvodina and Belgrade region were shared less, recording 1.31 and 1.38 shares per post. However, for this variable, results indicated highest score in case of Šumadija and West Serbia region, where posts received 3.58 shares on average.

Table 6. A comparison of engagement metrics on hotels Page posts, by region ( $\mathrm{N}$ - Number of posts; M- Mean; SDStandard deviation)

\begin{tabular}{|c|c|c|c|c|}
\hline & \multicolumn{4}{|c|}{ Vojvodina } \\
\hline & $\mathrm{N}$ & Total & M & SD \\
\hline Reactions & 4110 & 123107 & 29.96 & 118.76 \\
\hline Comments & 4110 & 2094 & 0.51 & 5.72 \\
\hline \multirow[t]{3}{*}{ Shares } & 4110 & 5365 & 1.31 & 4.93 \\
\hline & \multicolumn{4}{|c|}{ Belgrade } \\
\hline & $\mathrm{N}$ & Total & M & SD \\
\hline Reactions & 7157 & 318130 & 44.46 & 176.85 \\
\hline Comments & 7157 & 4037 & 0.56 & 2.86 \\
\hline \multirow[t]{3}{*}{ Shares } & 7157 & 9908 & 1.38 & 4.29 \\
\hline & \multicolumn{4}{|c|}{ Šumadija and West Serbia } \\
\hline & $\mathrm{N}$ & Total & M & SD \\
\hline Reactions & 7747 & 555531 & 71.72 & 158.67 \\
\hline Comments & 7747 & 8724 & 1.13 & 4.39 \\
\hline \multirow[t]{3}{*}{ Shares } & 7747 & 27737 & 3.58 & 18.21 \\
\hline & \multicolumn{4}{|c|}{ East and South Serbia } \\
\hline & $\mathrm{N}$ & Total & $M$ & SD \\
\hline Reactions & 3829 & 389803 & 101.83 & 272.8 \\
\hline Comments & 3829 & 6177 & 1.61 & 5.45 \\
\hline Shares & 3829 & 10539 & 2.75 & 8.35 \\
\hline
\end{tabular}

\section{Discussion and Conclusions}

The results of this overview study highlight current practices and regional similarities and differences in the use of the hotels Facebook Pages in the four regions in Serbia.

Firstly, this study offers a theoretical contribution, as it outlines a regional approach to the analysis of Facebook Pages in the context of hospitality markets within one country.

The approach used in this paper is based on contemporary social media metrics and it is open for further selection of variables for the assessment. This is also a low-demanding procedure of data collection as suggested by (Stankov et al., 2018; Stankov \& Filimonau, 2018). This paper also tries to facilitate the adoption of Facebook metrics by other hospitality researchers and practitioner in order to find applicable insights from this SNS.

This study offers diverse practical implications. Hotel managers can exercise suggested ideas to detect their competitive advantage concerning the practice of using Facebook Pages within the same sub-national regions that are often seen as a separate tourist destinations (for example, Belgrade and Vojvodina). In fact, this study produced results that show inconsistent practices in the four regions of Serbia. By adopting current destination standards, hotels that are lagging behind can add value to their Facebook marketing strategies.

Although, in case of all four regions, fans used reactions most often as a way of interacting with posted content on hotels pages, scores vary by the examined regions. This is true in cases of average number of reactions, which is more than three times higher in East and South Serbia region compared to Vojvodina region. The same can be said for average shares count, lowest in Vojvodina and Belgrade regions and highest in Šumadija and West Serbia region. Such findings indicate that number of fans does not necessarily mean higher engagement, that is, users may like Page of one hotel and become the fan, but they might rare- 
ly or never engage with Page's content. This emphasizes the importance of thorough planning and preparation of all aspects of communication of SNS platforms. All of that because user engagement can have a positive impact on overall image of a brand (Molinillo et al., 2018; Su et al., 2015)we identify four communication characteristics as critical drivers of friendship between hotel brands and consumers in the context of SNSs: self-disclosure, language similarity, interest similarity, and frequency of interaction with consumers (interaction frequency.

On the other hand, this study revealed interesting difference in fans' origin. Similarities among all four regions are noticeable in structure of fans in terms of country of origin. Fans from former Yugoslav republics represent the most part of foreign fans on hotels pages. This might be due to similarities among languages spoken in aforementioned countries, thus removing the language barrier, which is crucial for communication. Besides that, in case of Vojvodina, Šumadija and West Serbia and East and South Serbia, regions that border neighboring countries (Majstorović et al., 2013), fans from those countries represent the largest groups among all foreign fans. This emphasizes regional aspect of tourism development and importance of vicinity of destinations for foreign visits from neighboring countries. Due to the characteristics of Belgrade region, the same conclusion cannot be drawn, although in that case as well, fans from former Yugoslav republics represented around half of all the foreign fans, reinforcing the language barrier assumption. However, the results indicating the lowest percentage of domestic Page fans, in this region, can be a consequence of highest number of foreign visits (Statistical Office of the Republic of Serbia, 2017). This can possibly indicate that Belgrade, as a capital of Serbia and the largest city, represent a hub and a starting point for foreign visits. Results also indicate that greater variety in terms of fans country of origin does not necessarily mean high percentage of foreign fans. This is especially true for Šumadija and West Serbia region, where hotels have fans from highest number of countries, while at the same time the share of domestic fans is higher than in any other observed region, indicating prevalence of domestic tourism in this region.

In case of frequency of posting, higher number of daily posts does not have to be a priority of the hotels, since too frequent posting can have negative effect of user engagement (Mariani et al., 2018)and leveraging advanced metrics for capturing user engagement, the study sheds light on the factors contributing to superior level of social activity. The findings indicate that the way Facebook is tactically employed varies significantly across the NTOs. The panel data regres- sion analyses suggest that engagement is positively affected by posting visual content (namely photos. For example, the study found out that United Kingdom DMO Facebook page has the record fan base in the EU but have lowest levels of post frequency (Stankov et al., 2018). On the other hand, some authors (Chaffey \& Ellis-Chadwick, 2016; Pickton \& Broderick, 2001; Porter, 2001) state that, in order for communication on SNSs to be successful, companies should establish continuity of activity on their pages. Having that said, the specifics of hotel products and services should certainly be taken into account, especially in case of how often consumers use those products and services, as there is a difference compared to fast moving consumer goods (De Vries et al., 2012)messages, quizzes, information, and other material.

Daily distribution of posts showed different posting patterns for all four regions. Peak times ranged from around noon, in cases of Belgrade and Šumadija and West Serbia region, to peaks coinciding with beginning and an end of typical working hours in East and South Serbia region, to evenly distributed posting of hotels in Vojvodina region. Although, daily time of posting showed differences, and might be correlated to differences in user engagement, this assumption has to be taken with caution, since the content posted is seen by users when they log in to their accounts. This means that the algorithm used by SNSs to deliver content allows for seeing and engaging with it hours and even days after it was posted, diminishing importance of exact time of posting (Pletikosa Cvijikj \& Michahelles, 2013).

Average weekly distribution of posts is not significantly different between Belgrade and Šumadija and West Serbia regions and corresponds to global post frequency by days of the week, that is, posts are more frequent during workdays than weekends (Sabate et al., 2014; Stankov et al., 2018). In case of other two regions, Vojvodina and East and South Serbia, average weekly distribution of posts is evenly distributed throughout both workdays and weekends. However, in case of days of postings as a factor for user engagement, previous studies (De Vries et al., 2012; Mariani et al., 2016; Sabate et al., 2014)messages, quizzes, information, and other material resulted in different findings regarding weekdays and weekends, meaning that further analysis in that regard can improve existing knowledge.

Although average post length in all four regions fall under the Facebook recommended post length, which is between 100 and 250 characters, the engagement proved to be highest in case of East and South Serbia region, which is slightly under 200 characters. In that regard, recent study suggests that moderately long posts, around 200 characters, have statisti- 
cally significant positive impact on user engagement, which coincide with the results of this study (Mariani et al., 2016)and improves on the current metrics for capturing user engagement. Based on big data analysis from the regional DMOs' Facebook pages, supplemented with semi-structured interviews conducted with DMO managers, the study sheds light on the factors contributing to superior level of social activity. The findings indicate that the way Facebook is tactically and strategically employed varies significantly across Italian regional DMOs. Visual content (namely photos.

There are some limitations of this study. Content analysis was not included in the approach of this study. Such analysis, with the use of different analytical tools can very useful in revealing valuable insights to motives of users' engagement and perception to- wards brands (Cervellon \& Galipienzo, 2015). For example in case of users' engagement, Kwok and Yu's (2015) content analysis of Facebook messages posted by hospitality companies reveals that conversational messages receive more users' "Likes“ than sales/marketing messages. More precisely, the study of de Vries and colleagues (2012) showed that posts that contained question engaged more "Comments" than average. Another limitation is that this study did not examine hotels micro-location (as regions was used for data aggregation), which can explore potential differences in characteristics of hotels in urban and rural areas. Besides that, this study could not determine whether the posts were either sponsored or boosted. This information is only available to administrators of examined Facebook pages, on which the paid advertising was made.

\section{References}

Beauregard, R. (200o). Tourism and Economic Development Policy in US Urban Areas. In D. Ioannides \& K. Debbage (Eds.), The Economic Geography of the Tourist Industry: A Supply-side Analysis. London: Routlege.

Buhalis, D., \& O’Connor, P. (2005). Information Communication Technology Revolutionizing Tourism. Tourism Recreation Research, 30(3), 7-16. https://doi.org/10.1080/02508281.2005.11081482.

Cellan-Jones, R. (2012). Who 'likes' my Virtual Bagels. BBC News. Retrieved from https://www.bbc.com/ news/technology-18819338 (20.06.2018.)

Cervellon, M.C., \& Galipienzo, D. (2015). Facebook Pages Content, Does it Really Matter? Consumers' Responses to Luxury Hotel Posts with Emotional and Informational Content. Journal of Travel and Tourism Marketing, 32(4), 428-437. https://doi.org/1 $0.1080 / 10548408.2014 .904260$.

Chaffey, D., \& Ellis-Chadwick, F. (2016). Digital Marketing (6th ed.). Harlow: Pearson.

Chan, N.L., \& Guillet, B.D. (2011). Investigation of Social Media Marketing: How Does the Hotel Industry in Hong Kong Perform in Marketing on Social Media Websites. Journal of Travel and Tourism Marketing, 28(4), 345-368. https://doi.org/10.1080/10 548408.2011.571571.

De Vries, L., Gensler, S., \& Leeflang, P.S.H. (2012). Popularity of Brand Posts on Brand Fan Pages, nvestigation of the Effects of Social Media Marketing. Journal of Interactive Marketing, 26(2), 83-91. https://doi.org/10.1016/j.intmar.2012.01.003.

Dippelreiter, B., Grün, C., Pöttler, M., Seidel, I., Berger, H., Dittenbach, M., \& Pesenhofer, A. (2008). Online Tourism Communities on the Path to
Web 2.0 : An Evaluation. Information Technology and Tourism, 10(4), 329-353. https://doi. org/10.3727/109830508788403132.

Dragović, N., Cimbaljević, M., Stankov, U., Vasiljević, Đ., Vujičić, M.D., \& Pavluković, V. (2018). Former Yugoslav National Parks are Going Social? An Exploratory Study on Facebook. Turizam, 22(1), 10-18. https://doi.org/10.5937/22-17511.

Facebook for Business, (2018). Facebook Pages: Keeping Activity Authentic. Retrieved from https:/ www.facebook.com/business/a/page/fake-likes (20.06.2018)

Fan, S., Lau, R.Y.K., \& Zhao, J.L. (2015). Demystifying Big Data Analytics for Business Intelligence Through the Lens of Marketing Mix. Big Data Research, 2(1), 28-32. https://doi.org/10.1016/j. bdr.2015.02.006.

Gessler, K. (2016). Stop mindlessly following character count recommendations on Facebook posts. Retrieved from https://medium.com/@kurtgessler/ stop-mindlessly-following-character-count-recommendations-on-facebook-posts-eo1103b4d349 (25.10.2018.)

Gunn, C. (2002). Tourism Planning. New York: Taylor and Francis.

He, W., Zha, S., \& Li, L. (2013). Social media competitive analysis and text mining: A case study in the pizza industry. International Journal of Information Management, 33, 464-472. https://doi.org/10.1016/j. ijinfomgt.2013.01.001.

Hsu, Y. (2012). Facebook as international eMarketing strategy of Taiwan hotels. International Journal of Hospitality Management, 31(3), 972-980. doi:10.1016/j.ijhm.2011.11.005 
Huang, L., Yung, C.Y., \& Yang, E. (2011). How do travel agencies obtain a competitive advantage?: Through a travel blog marketing channel. Journal of Vacation Marketing, 17(2), 139-149. https://doi. org/10.1177/1356766710392737.

Huang, Y., Basu, C., \& Hsu, M.K. (2010). Exploring Motivations of Travel Knowledge Sharing on Social Network Sites: An Empirical Investigation of U.S. College Students. Journal of Hospitality Marketing and Management, 19(7), 717-734. https://doi.org/10.1 080/19368623.2010.508002.

Internet world stats. (2018). Europe Internet Usage Stats Facebook Subscribers and Population Statistics. Retrieved from https://www.internetworldstats.com/stats4.htm (21.07.2018.)

Inversini, A., Cantoni, L., \& Buhalis, D. (2009). Destinations' Information Competition and Web Reputation. Information Technology and Tourism, 11(3), 221-234. https://doi.org/10.3727/10983050 9X12596187863991.

Inversini, A., \& Masiero, L. (2014). Selling rooms online: the use of social media and online travel agents. International Journal of Contemporary Hospitality Management, 26(2), 272-292. https://doi. org/10.1108/IJCHM-03-2013-0140.

Jovanović, T., Božić, S., Bodroža, B., \& Stankov, U. (2018). Influence of users' psychosocial traits on Facebook travel-related behavior patterns. Journal of Vacation Marketing, https://doi. org/10.1177/1356766718771420.

Kaplan, A.M., \& Haenlein, M. (2010). Users of the world, unite! The challenges and opportunities of Social Media. Business Horizons, 53(1), 59-68. https://doi.org/10.1016/j.bushor.2009.09.003.

Kasavana, M.L., Nusair, K., \& Teodosic, K. (2010). Online social networking: redefining the human web. Journal of Hospitality and Tourism Technology, 1(1), 68-82. https://doi. org/10.1108/17579881011023025.

Kemp, S. (2018). Digital in 2018: World's internet users pass the 4 billion mark - We Are Social UK. Retrieved from https://wearesocial.com/uk/blog/2018/o1/ global-digital-report-2018.

Kimes,S.E.(2008). TheRoleofTechnologyin Restaurant Revenue Management. Cornell Hospitality Quarterly, 49(3), 297-309. doi:10.1177/1938965508322768

Kwok, L., \& Yu, B. (2013). Spreading Social Media Messages on Facebook. Cornell Hospitality Quarterly, 54(1), 84-94. https://doi. org/10.1177/1938965512458360.

Ladhari, R., \& Michaud, M. (2015). EWOM effects on hotel booking intentions, attitudes, trust, and website perceptions. International Journal of Hospitality Management, 46, 36-45. https://doi.org/10.1016/j. ijhm.2015.01.010.
Law, R., \& Jogaratnam, G. (2005). A study of hotel information technology applications. International Journal of Contemporary Hospitality Management, 17(2), 170-18o. https://doi.org/10.1108/09596110510582369.

Lee, K.H., Kang, S., Terry, W.C., \& Schuett, M.A. (2018). A spatial relationship between the distribution patterns of hotels and amenities in the United States. Cogent Social Sciences, 4(1), https://doi.org/1 0.1080/23311886.2018.1444918.

Li, X., \& Wang, Y. (2011). China in the Eyes of Western Travelers as Represented in Travel Blogs. Journal of Travel and Tourism Marketing, 28(7), 689-719. https://doi.org/10.1080/10548408.2011.615245.

Litvin, S.W., Goldsmith, R.E., \& Pan, B. (2008). Electronic word-of-mouth in hospitality and tourism management. Tourism Management, 29(3), 458-468. https://doi.org/10.1016/J.TOURMAN.2007.05.011.

Lo, I.S., Mckercher, B., Lo, A., Cheung, C., \& Law, R. (2011). Tourism and online photography. Tourism Management, 32(4), 725-731. https://doi.org/10.1016/J. TOURMAN.2010.06.001.

Lu, W., \& Stepchenkova, S. (2015). User-Generated Content as a Research Mode in Tourism and Hospitality Applications: Topics, Methods, and Software. Journal of Hospitality Marketing and Management, 24(2), 119-154. https://doi.org/10.1080/1936 8623.2014.907758.

Luo, H., \& Yang, Y. (2013). Spatial pattern of hotel distribution in China. Tourism and Hospitality Research, 13(1), 3-15. https://doi. org/10.1177/1467358413508579.

Majstorović, V., Stankov, U., \& Stojanov, S. (2013). Pogranične regrije kao turističke destinacije [Border regions as the tourist destination]. Škola Bizni$s a, 2,15-29$.

Mariani, M.M., Di, F.M., \& Mura, M. (2016). Facebook as a destination marketing tool: Evidence from Italian regional Destination Management Organizations. Tourism Management, 54, 321-343. https:// doi.org/10.1016/j.tourman.2015.12.008.

Mariani, M.M., Mura, M., \& Di, F.M. (2018). The determinants of Facebook social engagement for national tourism organizations' Facebook pages: A quantitative approach. Journal of Destination Marketing and Management, 8, 312-325. https://doi. org/10.1016/J.JDMM.2017.06.003.

Marine-Roig, E., \& Anton, C.S. (2015). Tourism analytics with massive user-generated content: A case study of Barcelona. Journal of Destination Marketing and Management, 4(3), 162-172. https://doi. org/10.1016/j.jdmm.2015.06.004.

Mccarthy, L., Stock, D., \& Verma, R. (2010). How Travelers Use Online and Social Media Channels to Make Hotel-choice Decisions. Center for Hospital- 
ity Research Publications. Retrieved from https:// scholarship.sha.cornell.edu/chrpubs/97.

Molinillo, S., Liébana-Cabanillas, F., Anaya-Sánchez, R., \& Buhalis, D. (2018). DMO online platforms: Image and intention to visit. Tourism Management, 65, 116-130. https://doi.org/10.1016/j.tourman.2017.09.021.

O'Connor, P. (2011). An Analysis of the Use of Facebook by International Hotel Chains. In International CHRIE Conference-Refereed Track. Retrieved from https://scholarworks.umass.edu/refereed/ ICHRIE_2011/Wednesday/9.

Pan, B., Zhang, L., \& Law, R. (2013). The Complex Matter of Online Hotel Choice. Cornell Hospitality Quarterly, 54(1), 74-83. https://doi. org/10.1177/1938965512463264h.

Pantelidis, I.S. (2010). Electronic Meal Experience: A Content Analysis of Online Restaurant Comments. Cornell Hospitality Quarterly, 51(4), 483-491. doi:10.1177/1938965510378574

Peck, J., Theodore, N., \& Brenner, N. (2009). Neoliberal Urbanism: Models, Moments, Mutations. SAIS Review, 29(1), 49-66. https://doi.org/10.1353/sais.0.0028.

Pickton, D., \& Broderick, A. (2001). Integrated Marketing Communications. Harlow: Pearson. Retrieved from www.pearson-books.com.

Cvijikj, P.I., \& Michahelles, F. (2013). Online engagement factors on Facebook brand pages. Social Network Analysis and Mining, 3(4), 843-861. https://doi. org/10.1007/s13278-013-0098-8.

Porter, M.E. (2001). Strategy and the Internet. Harvard Business Review.

Rieder, B. (2013). Studying Facebook via Data Extraction: The Netvizz Application. http://thepoliticsofsystems.net/permafiles/rieder_websci.pdf.

Roque, V., \& Raposo, R. (2016). Social media as a communication and marketing tool in tourism: an analysis of online activities from international key player DMO. Anatolia, 27(1), 58-70. https://doi.org/1 0.1080/13032917.2015.1083209.

Sabate, F., Berbegal-Mirabent, J., Cañabate, A., \& Lebherz, P.R. (2014). Factors influencing popularity of branded content in Facebook fan pages. European Management Journal, 32(6), 1001-1011. https://doi. org/10.1016/j.emj.2014.05.001.

Schmallegger, D., \& Carson, D. (2008). Blogs in tourism: Changing approaches to information exchange. Journal of Vacation Marketing, 14(2), 99110. https://doi.org/10.1177/1356766707087519.

Sharpley, R., \& Telfer, D.J. (2014). Tourism and development: Concepts and issues.

Sparks, B.A., \& Browning, V. (2011). The impact of online reviews on hotel booking intentions and perception of trust. Tourism Management, 32(6), 1310-1323. https://doi.org/10.1016/J.TOURMAN.2010.12.011.
Stankov, U., Armenski, T., Klauco, M., Pavluković, V., Cimbaljević, M., \& Drakulić-Kovačević, N. (2017). Spatial autocorrelation analysis of tourist arrivals using municipal data: A Serbian example. Geographica Pannonica, 21(2), 106-114. https://doi. org/10.18421/GP21.02-04

Stankov, U., \& Filimonau, V. (2018). Reviving calm technology in the e-tourism context. The Service Industries Journal, 1-18. https://doi.org/10.1080/026 42069.2018.1544619.

Stankov, U., Jovanović, T., Pavluković, V., Kalinić, Č., Drakulić-Kovačević, N., \& Cimbaljević, M. (2018). A regional survey of current practices on destination marketing organizations' Facebook pages: The case of EU and U. S. Geographica Pannonica, 22(2), 81-96. https://doi.org/10.5937/22-16673.

Stankov, U., Lazić, L., \& Dragićević, V. (2010). The extent of use of basic facebook user-generated content by the national tourism organizations in $\mathrm{Eu}$ rope. European Journal of Tourism Research, 3(2), 105-113.

Statistical Office of the Republic of Serbia. (2017). Municipalities and Regions in Republic of Serbia.

$\mathrm{Su}, \mathrm{N}$., Mariadoss, J.B., \& Reynolds, D. (2015). Friendship on social networking sites: Improving relationships between hotel brands and consumers. International Journal of Hospitality Management, 51, 76-86. https://doi.org/10.1016/j.ijhm.2015.08.009.

Truchet, S., Callois, J.M., Aubert, F., \& Piguet, V. (2011). Amenities and location of hotels: A microeconomic model and estimations. ERSA conference papers. https://econpapers.repec.org/paper/wiwwiwrsa/ersa1op904.htm.

Tussyadiah, I., Park, S., \& Fesenmaier, D.R. (2011). Assessing the Effectiveness of Consumer Narratives for Destination Marketing. Journal of Hospitality and Tourism Research, 35(1), 64-78. https://doi. org/10.1177/1096348010384594.

Xiang, Z., \& Gretzel, U. (2010). Role of social media in online travel information search. Tourism Management, 31(2), 179-188. https://doi.org/10.1016/J. TOURMAN.2009.02.016.

Xiang, Z., Schwartz, Z., Gerdes, J.H., \& Uysal, M. (2015). What can big data and text analytics tell us about hotel guest experience and satisfaction. International Journal of Hospitality Management, 44, 120-130. https://doi.org/10.1016/j.ijhm.2014.10.013.

Ye, Q., Law, R., Gu, B., \& Chen, W. (2011). The influence of user-generated content on traveler behavior: An empirical investigation on the effects of e-word-of-mouth to hotel online bookings. Computers in Human Behavior, 27(2), 634-639. https:// doi.org/10.1016/J.CHB.2010.04.014.

Yoo, K.H., \& Gretzel, U. (2012). Use and creation of social media by travellers. In M. Sigala, E. Christou, 
\& U. Gretzel (Eds.), Social media in travel, tourism and hospitality. (pp. 189-205). UK: Ashgate.

Zivkovic, R., Njegus, A., Zlatanovic, M., Gajic, J., \& Brdar, I. (2015). Comparative analysis of Facebook and communication activities of the mountain hotels in Stara Planina, Kopaonik and Zlatibor. The
European Journal of Applied Economics, 12(1), 26-36. https://doi.org/10.5937/ejae12-8159.

Zouganeli, S., Trihas, N., \& Antonaki, M. (2012). Social media and tourism: the use of Facebook by the European national tourism organizations. Tourism Today, 11, 110-121. 